\title{
Population based mortality surveillance in carbon products manufacturing plants
}

\author{
M JANE TETA, M G OTT, A R SCHNATTER \\ From the Union Carbide Corporation, HS \& EA, Section P2, Danbury, Connecticut 06817-0001, USA
}

ABSTRACT The utility of a population based, corporate wide mortality surveillance system was evaluated after a 10 year observation period of one of the company's divisions. The subject population, 2219 white male, long term employees from Union Carbide Corporation's carbon base electrode and specialty products operations, was followed up for mortality from 1974 to 19830 . External comparisons with the United States male population were supplemented with internaq comparisons among subgroups of the study population, defined by broad job categories and time related variables, adjusting for important correlates of the healthy worker effect. Significant deficits of deaths were observed for all causes and the major non-cancer causes of death. The numbers of deaths due to malignant neoplasms and respiratory cancer were less than, but not statisticall different from, expected. There was a non-significant excess of deaths from lymphopoietic cancer $\vec{c}_{\bar{\delta}}$ occurring predominantly among salaried employees. When specific locations were examined, opero ations with potential exposure to coal tar products exhibited a mortality pattern similar to that of the total cohort. The risk for lung cancer was significantly raised (five observed, 1.4 expected) in ond small, but older, location which did not involve coal tar products during the period of employmen⿳亠口冋. of these individuals, but which historically used asbestos materials for several unique applicationsy Although these findings are limited by small numbers and a short observation period, the populatio 8 based surveillance strategy has provided valuable information regarding the mortality experience of the population, directions for future research, and the allocation of epidemiological resources.

An important first step in evaluating the effect of workplace exposures on the health of employees is to determine the most productive use of epidemiological resources. Where specific environmental health concerns have been recognised, a high priority must be assigned to investigating these matters directly through a rigorous research effort. In the absence of such concerns a continuing surveillance programme may be helpful in identifying areas for more intensive epidemiological research by providing a broad assessment of employees' health relative to the potential for exposure across the entire workforce. With surveillance, less comprehensive information is collected than would typically be required in an investigation of a specific issue. This lack of detail, however, usually facilitates the rapid collection, analysis, and assessment of the available data. Even though it is not targeted to address specific issues, an existing surveillance system may fortuitously provide data with which to respond rapidly to questions raised by new

Accepted 8 July 1986 toxicological and medical findings. Surveillance mas. also provide a measure of reassurance that the worts environment is a safe one. Thus there are several com $\$$ pelling reasons to include surveillance among theactivities of an occupational health programme.

In 1978 the epidemiology unit of the Union Carbidg Corporation (UCC) initiated a population based mor tality surveillance system in one of the company' major operating groups, the carbon products division (CPD). An important objective of this project was to. evaluate the informativeness of such a system and its. usefulness in detecting health effects that may be due to occupational factors.

The choice of the CPD for testing population based surveillance within the company was motivated by: (\& the recognition that several of the materials used if these manufacturing operations, particularly coal taf products, petroleum coke, and asbestos, could pose potential health hazards; (2) the lack of published data on the health experience of workers engaged i $\overline{8}$ the production of carbon based electrodes an $\vec{\phi}$ specialty products, and (3) the availability of computit erised payroll data for the division. 


\section{Methods}

For several years, the carbon products division has maintained a computerised payroll file of employees that contains limited work history and demographic data. Job assignment information consisting of location, job code, reason for termination, continuous service dates, paytype, and demographic data were extracted from the central file to construct and annually update the database for the study. To facilitate the conduct of the research and maximise the information obtained, surveillance was restricted to individuals who were employed at one of the 11 active locations on 1 January 1974 and who had had at least 10 years of prior company service in Union Carbide. There were 2529 employees eligible for follow up and the period of observation was from 1974 to 1983 . Table 1 gives a description of the six largest locations with their respective numbers of employees. Five carbon products division locations that contributed fewer than 100 employees each are not included in table 1.

Employment status was updated annually with the given reason for termination for those individuals no longer active. Vital status was periodically verified from the payroll tapes, the company's benefits department, and from the records of the Social Security Administration. Death certificates were coded by a trained nosologist according to the rules of the International Classification of Diseases, 8th rev.

Analyses were restricted to 2219 white men (64 men of unknown race were assumed to be white), since eligible non-white men $(n=160)$ and women $(n=$ 150 ) were few in number. Using a modified life table analysis program, observed deaths for 82 cause of death categories were compared with the number that would be expected if this population had experienced the same mortality rates as the United States white male population. ${ }^{1}$ The summary measure was the ratio of observed to expected deaths multiplied by
100 -that is, the standardised mortality ratio (SMR). Ninety five per cent confidence limits were calculated using the programs of Rothman and Boice. ${ }^{2}$ Overall and location specific SMRs for the six largest locations were computed. External death rates used in the analyses were taken from the National Institute for Occupational Safety and Health (NIOSH) life table program. ${ }^{3}$ Since United States death rates were available only up to 1978 , the $1975-8$ rates were used for the entire 1975-83 period of observation. The lack of national death rate data to 1983 imparts a small bias to the SMRs due to secular mortality trends not properly reflected in the comparisons. For example, there has been a $2 \cdot 1 \%$ average annual decline in overall age adjusted mortality between 1970 and $1983^{4}$ and an estimated $2.6 \%$ annual decline in mortality from ischaemic heart disease during the 1970 s. $^{5}$ Based on these trends an $8-9 \%$ overstatement of total expected deaths would be expected for the 1980-3 observation period. Similarly, an understatement of expected deaths would be expected for causes of death that are secularly increasing such as lung cancer.

A major disadvantage of relying on a general population comparison group is that community populations are not subject to the selection effects that exist for a working population. ${ }^{6}{ }^{7}$ An employed population typically experiences lower death rates than the general population, since those medically unsuited for employment are less likely to enter the workforce either by voluntarily refraining from seeking employment or by exclusion as a consequence of preemployment screening. A continuing survival advantage of active employees has also been shown. ${ }^{89}$ These effects are greatest in the early years of follow up and thus would be expected in this study because of the maximum 10 year follow up period. There are also other important factors related to mortality, for which a general population may differ from an occupational cohort, further complicating the inter-

Table 1 Description of the six largest carbon products division locations in surveillance study

\begin{tabular}{|c|c|c|c|c|c|}
\hline Plant & State & $\begin{array}{l}\text { No* of } \\
\text { employees } \\
\text { in study }\end{array}$ & Start up & Products \& processes & Exposures \\
\hline $\operatorname{Loc} A$ & WV & 330 & 1904 & $\begin{array}{l}\text { Synthetic graphite electrodes \& specialty products/calcining } \\
\text { to finishing using petroleum coke \& coal tar pitch.as raw } \\
\text { materials }\end{array}$ & $\begin{array}{l}\text { Pitch, CTPVs, silica, } \\
\text { chlorine, \& asbestos }\end{array}$ \\
\hline Loc B & TN & 545 & 1937 & $\begin{array}{l}\text { Coal and graphite electrodes/same processes as loc } \mathrm{A} \text { with } \\
\text { the addition of calcining of anthracite coal }\end{array}$ & Similar to loc $\mathbf{A}$ \\
\hline Loc C & $\mathrm{OH}$ & 109 & 1891 & $\begin{array}{l}\text { Arc carbons, carbon brushes, heat exchangers (1937); boron } \\
\text { nitride (1965); gaskets \& shock absorbers (1968) }\end{array}$ & $\begin{array}{l}\text { Formaldehyde, furfural, } \\
\text { furfuryl alcohol, } \\
\text { silica, \& asbestos }\end{array}$ \\
\hline $\begin{array}{l}\text { Loc D } \\
\text { Loc E } \\
\text { Loc F }\end{array}$ & $\begin{array}{l}\mathrm{OH} \\
\mathrm{NY} \\
\mathrm{OH}\end{array}$ & $\begin{array}{l}404 \\
414 \\
228\end{array}$ & $\begin{array}{l}1892 \\
1915 \\
1890 s\end{array}$ & $\begin{array}{l}\text { Small carbon \& graphite specialties/processes similar to loc A } \\
\text { Carbon \& graphite electrodes/processes similar to loc A } \\
\text { Res \& dev carbon technology \& electrochemistry }\end{array}$ & $\begin{array}{l}\text { Similar to loc A } \\
\text { Similar to loc A } \\
\text { All }\end{array}$ \\
\hline
\end{tabular}

*Includes all sex and race groups.

$\mathrm{CTPV}=$ Coal tar pitch volatiles. 
pretation of the findings. These include differences in access to medical care, socioeconomic status, smoking, and drinking habits. Comparisons with the general population based on indirect standardisation are subject to an additional drawback. The SMRs computed for various subcohorts may not be mutually comparable because each estimate is standardised to the stratum weights of the particular subcohort being investigated. ${ }^{10}$

To assess the potential impact of several correlates of the healthy employee selection effect, internal analyses were performed relating mortality experience to general job category (A: supervisory, research, and office employees; B: crafts; and C: operators, labourers, and service), age at hire (15-24, 25-34, and $\geqslant 35$ years), prior years of employment $(10-19,20-29, \geqslant 30$ years), and interval since entry to study $(0-4,5-9$ years). Job category, as defined, reflects both socioeconomic differences and differences in potential for occupational exposures. Internal comparisons of a particular location to all other locations combined were also performed where needed to supplement external analyses. Details of this analysis have been presented elsewhere. ${ }^{1}$ In brief, the levels of each factor are compared, using a stratification approach to control for possible confounding due to the remaining variables. Mutually comparable conditional risk ratios are derived and summary chi-squared statistics are calculated to test for differences among groups and evidence of linear trend for each factor under investigation.

A population based approach to surveillance was favoured over an event based (proportionate mortality) approach for several reasons. Firstly, the availability of population data allows a comparison of death rates rather than simply a comparison of proportional causes of death. Thus differences in overall death rates will not distort the cause specific comparisons. Secondly, additional research, such as a nested case/control study, is easier to plan because basic information for a large portion of the target population will have already been collected. Finall the population based approach is readily expandab尺 to other health outcomes. For example, the registr could be linked with information on medical visits questionnaire mailings or periodic health informat tion, and providing a mechanism for examining mo $\frac{\mathcal{E}}{\mathrm{E}}$ bidity among subgroups of our employee populatio and for determining participating rates where appr® priate.

\section{Results}

The vital and employment status of the white mate component of the surveillance population are described on 1 January 1984 in table 2 . Of the $221 \frac{8}{9}$ participants, $883(39.8 \%)$ were still actively employed $897(40.4 \%)$ had retired, $210(9.5 \%)$ had terminate $\$$ employment for other reasons and were known to bs alive, and $223(10 \%)$ had died. Only six men were lost to follow up. Copies of death certificates were obtained for all those who had died.

Table 3 presents the observed and expected num= bers of deaths for white men in the study by cause of death category. Significant deficits of deaths due to alN causes (SMR $=67$ ), diseases of the circulatory systerf $(\mathrm{SMR}=60)$, diseases of the respiratory system (SM $=51)$, accidents $($ SMR $=22)$, and suicide (SMR 16) were observed. Deaths due to total malignant neos plasms (SMR $=93$ ), cancer of the respiratory systeri $(\mathrm{SMR}=85)$, cerebrovascular disease $(\mathrm{SMR}=67)$ and cirrhosis of the liver $(S M R=45)$ were less thay expected. The SMRs for these causes of death, hows ever, were not statistically different from 100 . Thero were non-significant increased numbers of deaths observed for lymphopoietic cancer $($ SMR $=176)$ an residual cancer $(S M R=123)$. Among the subcategories within the broader category of lympho poietic cancer were five deaths $(2 \cdot 4$ expected) due to. non-Hodgkin's lymphoma and four (1.2 expected due to multiple myeloma. Neither difference was stas

Table 2 Vital and employment status of surveillance population by location on 1 January 1984

\begin{tabular}{|c|c|c|c|c|c|c|}
\hline \multirow[b]{3}{*}{ Population group } & \multicolumn{6}{|c|}{ Vital status } \\
\hline & \multirow[b]{2}{*}{ Total } & \multicolumn{3}{|c|}{ Alive $(n=1990)$} & \multirow[b]{2}{*}{ Unknown } & \multirow[b]{2}{*}{ Deceased } \\
\hline & & Working & Retired & Left co & & \\
\hline $\begin{array}{l}\text { Total eligible white men: } \\
\text { Location A } \\
\text { Location B } \\
\text { Location C } \\
\text { Location D } \\
\text { Location E } \\
\text { Location F } \\
\text { Other locations }\end{array}$ & $\begin{array}{r}2219 \\
315 \\
537 \\
104 \\
404 \\
414 \\
228 \\
243\end{array}$ & $\begin{array}{r}883 \\
64 \\
237 \\
42 \\
159 \\
137 \\
111 \\
133\end{array}$ & $\begin{array}{r}897 \\
160 \\
206 \\
45 \\
157 \\
170 \\
91 \\
68\end{array}$ & $\begin{array}{r}210 \\
46 \\
42 \\
4 \\
23 \\
61 \\
12 \\
22\end{array}$ & $\begin{array}{l}6 \\
2 \\
0 \\
0 \\
2 \\
0 \\
1 \\
1\end{array}$ & $\begin{array}{r}223 \\
43 \\
52 \\
13 \\
37 \\
46 \\
13 \\
19\end{array}$ \\
\hline
\end{tabular}


Table 3 Observed and expected $\dagger$ deaths by cause for 2219 white men

\begin{tabular}{|c|c|c|c|}
\hline Cause of death category & Observed/expected & $S M R \ddagger$ & $95 \% \mathrm{CI}$ \\
\hline $\begin{array}{l}\text { All causes } \\
\text { Malignant neoplasms, total } \\
\text { Buccal cavity and pharynx } \\
\text { Digestive organs \& peritoneum } \\
\text { Respiratory system } \\
\text { Genital organs } \\
\text { Urinary organs } \\
\text { Brain \& other parts of nervous system } \\
\text { Lymphatic and haematopoietic tissue } \\
\text { Residual } \\
\text { Diabetes mellitus } \\
\text { Cerebrovascular disease } \\
\text { Diseases of the circulatory system } \\
\text { Diseases of the respiratory system } \\
\text { Cirrhosis of the liver } \\
\text { Accidents } \\
\text { Suicide } \\
\text { Residual }\end{array}$ & $\begin{array}{c}223 / 335 \cdot 1 \\
78 / 83 \cdot 5 \\
0 / 2 \cdot 8 \\
20 / 21 \cdot 3 \\
29 / 34 \cdot 3 \\
4 / 4 \cdot 2 \\
4 / 4 \cdot 3 \\
0 / 2 \cdot 5 \\
12 / 6 \cdot 8 \\
9 / 7 \cdot 3 \\
4 / 4 \cdot 6 \\
11 / 16 \cdot 5 \\
91 / 151 \cdot 8 \\
10 / 19 \cdot 7 \\
5 / 11 \cdot 1 \\
3 / 13 \cdot 8 \\
1 / 6 \cdot 3 \\
20 / 27 \cdot 8\end{array}$ & $\begin{array}{l}67^{*} \\
93 \\
\| \\
94 \\
85 \\
\| \\
\| \\
176 \\
123 \\
\| \\
67 \\
60^{*} \\
51^{*} \\
45 \\
22^{*} \\
16^{*} \\
72\end{array}$ & $\begin{array}{l}(55-72) \\
(74-117) \\
(0-131) \\
(57-145) \\
(57-121) \\
(26-243) \\
(25-238) \\
(0-148) \\
(91-308) \\
(56-234) \\
(24-223) \\
(33-119) \\
(48-74) \\
(24-93) \\
(15-105) \\
(12-85) \\
(0-88) \\
(44-111)\end{array}$ \\
\hline
\end{tabular}

$* \mathrm{p}<0.05$

+ Expected deaths calculated based on United States white male mortality rates, 1974-9.

tSMR $=0 / \mathrm{E} \times 100$

$\$ 95 \%$ confidence limits based on Fisher exact limits when number of observed deaths was less than 10 and approximate limits otherwise. $\|$ Both observed and expected have fewer than five deaths.

Table 4 Conditional risk ratios by cause of death and job categories. (Observed numbers of deaths in parentheses)

\begin{tabular}{|c|c|c|c|c|c|}
\hline \multirow[b]{2}{*}{ Cause of death category } & \multirow{2}{*}{$\begin{array}{l}\text { Job group A } \\
\text { Supervisory, research, } \\
\text { and office employees }\end{array}$} & \multirow{2}{*}{$\begin{array}{l}\text { Job group B } \\
\text { Crafts }\end{array}$} & \multicolumn{2}{|l|}{$J o b$ group $C$} & \multirow[b]{2}{*}{ Trend $\dagger p$ value } \\
\hline & & & $\begin{array}{l}\text { Operators, labourers, } \\
\text { service }\end{array}$ & Among* group p value & \\
\hline $\begin{array}{l}\text { All causes } \\
\text { All cancer } \\
\text { Digestive organs and }\end{array}$ & $\begin{array}{l}0.8(55) \\
0.9(22)\end{array}$ & $\begin{array}{l}1.4(46) \\
1 \cdot 2(14)\end{array}$ & $\begin{array}{l}1.0(122) \\
1.0(42)\end{array}$ & $\begin{array}{l}0.01 \\
0.56\end{array}$ & $\begin{array}{l}0.17 \\
0.55\end{array}$ \\
\hline $\begin{array}{l}\text { peritoneum } \\
\text { Respiratory system } \\
\text { Lymphatic \& haematopoietic }\end{array}$ & $\begin{array}{l}1.0(7) \\
0 \cdot 4(3)\end{array}$ & $\begin{array}{l}(4 / 2 \cdot 7) \ddagger \\
1 \cdot 3(6)\end{array}$ & $\begin{array}{l}0.9(9) \\
1 \cdot 2(20)\end{array}$ & $\begin{array}{l}0.68 \\
0.09\end{array}$ & $\begin{array}{l}0 \cdot 70 \\
0 \cdot 05\end{array}$ \\
\hline $\begin{array}{l}\text { tissue } \\
\text { Cerebrovascular disease } \\
\text { Diseases of the circulatory system } \\
\text { Diseases of the respiratory system }\end{array}$ & $\begin{array}{l}1 \cdot 9(7) \\
(1 / 2 \cdot 5) \ddagger \\
0 \cdot 8(24) \\
(1 / 2 \cdot 5) \ddagger\end{array}$ & $\begin{array}{l}(1 / 1 \cdot 8) \ddagger \\
3 \cdot 0(5) \\
1 \cdot 4(18) \\
(2 / 1 \cdot 5) \ddagger\end{array}$ & $\begin{array}{l}0 \cdot 6(4) \\
0 \cdot 7(5) \\
1 \cdot 0(49) \\
1 \cdot 2(7)\end{array}$ & $\begin{array}{l}0 \cdot 12 \\
0 \cdot 02 \\
0 \cdot 18 \\
0 \cdot 52\end{array}$ & $\begin{array}{l}0.06 \\
0.91 \\
0 \cdot 39 \\
0 \cdot 35\end{array}$ \\
\hline
\end{tabular}

*Probability of obtaining the observed risk ratios given the null hypothesis of no difference between the job category groupings.

†Probability of obtaining the observed risk ratios given the null hypothesis of not increasing or decreasing linear association assigning scores of 1,2 , and 3 for the three categories, respectively.

$\ddagger$ Risk ratios not calculated if observed and expected values are both less than 5 , in which case both the observed and expected deaths are provided in parentheses.

tistically significant based on computed $95 \%$ confidence limits.

Job category, age at hire, prior years of employment, and time since entry were individually examined within the total surveillance population, controlling for each of the other factors by stratification. The results of job category comparisons are presented in table 4. Analyses were performed only for those cause of death categories with 10 or more observed deaths in the total surveillance population. Group differences were observed for all causes of death combined and for cerebrovascular disease. In both instances the conditional risk ratios (ratio of observed to internal expected deaths) were lowest among the supervisory, research, and office employees (job group A) and highest among the craft employees (job group B). There was also an increasing trend in the risk ratio for respiratory cancer $(p=0.05)$ and a decreasing trend in the risk ratio for lymphopoietic cancer $(p=0.06)$ as job group changed from $A$ to $C$.

Although no statistically significant differences were observed for either age at hire or interval since entry, there was a non-significant trend of relatively higher mortality with increased interval since entry. Eighty one deaths occurred during the first five years of observation (risk ratio $=0.8$ ) and 142 deaths occurred during the second five years interval (risk ratio $=1 \cdot 1)$. This reflects an approximate $37 \%$ rela- 
Table 5 Standardised mortality ratios by cause of death category for six locations. (Observed numbers of deaths in parenthese $\frac{\pi}{8}$

\begin{tabular}{|c|c|c|c|c|c|c|}
\hline Cause of death category & $\operatorname{Loc} A$ & $\operatorname{Loc} B$ & $\operatorname{Loc} D$ & Loc $E$ & $\operatorname{Loc} F$ & $\operatorname{Loc} C$ \\
\hline $\begin{array}{l}\text { All causes } \\
\text { Malignant neoplasms, total } \\
\text { Digestive organs \& peritoneum } \\
\text { Respiratory system } \\
\text { Lymphatic \& haematopoietic tissue } \\
\text { Cerebrovascular disease } \\
\text { Diseases of the circulatory system } \\
\text { Diseases of the respiratory system } \\
\text { External causes } \\
\text { Residual }\end{array}$ & $\begin{array}{l}72 *(43) \\
99(15) \\
154(6) \\
113(7) \\
(0 / 1 \cdot 1) \dagger \\
(2 / 3 \cdot 1) \dagger \\
77(21) \\
(1 / 3 \cdot 8) \dagger \\
(1 / 3 \cdot 2) \dagger \\
43(3)\end{array}$ & $\begin{array}{l}68 *(52) \\
79(15) \\
(3 / 4 \cdot 8) \dagger \\
76(6) \\
(3 / 1 \cdot 6) \dagger \\
(4 / 3 \cdot 6) \dagger \\
49 *(17) \\
117(5) \\
19(1) \\
103(10)\end{array}$ & $\begin{array}{l}67^{*}(37) \\
88(12) \\
(2 / 3 \cdot 5) \dagger \\
54(3) \\
(1 / 1 \cdot 1) \dagger \\
(1 / 2 \cdot 8) \dagger \\
65(16) \\
(0 / 3 \cdot 3) \dagger \\
(1 / 3 \cdot 7) \dagger \\
104(7)\end{array}$ & $\begin{array}{l}72 *(46) \\
100(16) \\
(3 / 4 \cdot 1) \dagger \\
76(5) \\
(4 / 1 \cdot 3) \dagger \\
(0 / 3 \cdot 1) \dagger \\
79(23) \\
(2 / 3 \cdot 7) \dagger \\
(2 / 4 \cdot 1) \dagger \\
38(3)\end{array}$ & $\begin{array}{c}38^{*}(13) \\
35(3) \\
(2 / 2 \cdot 2) \dagger \\
(0 / 3 \cdot 5) \dagger \\
(1 / 0 \cdot 7) \dagger \\
(2 / 1 \cdot 7) \dagger \\
45^{*}(7) \\
(1 / 2 \cdot 1) \dagger \\
(0 / 2 \cdot 3) \dagger \\
(0 / 4 \cdot 3) \dagger\end{array}$ & $\begin{array}{c}89(13) \\
220(8) \\
(2 / 0.9) \dagger \\
336 *(5) \\
(0 / 0.3) \dagger \\
(0 / 0.7) \dagger \\
30(2) \\
(1 / 0.8) \dagger \\
(1 / 1.0) \dagger \\
(1 / 1.8) \dagger\end{array}$ \\
\hline
\end{tabular}

* Statistically different from 100 at the 0.05 level of significance.

tSMR not calculated if observed and expected numbers of deaths are both less than 5 in which case both the observed and expected deat are provided in parentheses.

tive increase in mortality during the second five year follow up. Despite this increase, the SMR of 72 for the latter period indicates that mortality remained less than that of the United States white male population. Further examination of cause specific patterns of mortality with respect to interval since entry and age at hire showed no notable findings.

No relation was found between prior years of employment $(10-19,20-29, \geqslant 30$ years) and overall mortality experience. The conditional risk ratio was lowest in the $10-19$ years group (risk ratio $=0.8$ ), highest in the 20-29 years group (risk ratio $=1 \cdot 1$ ), and intermediate in the $\geqslant 30$ years group (risk ratio = 1.0). Among cause specific comparisons, there was a significant correlation between mortality due to circulatory disease and prior years of employment $(\mathrm{p}=$ 0.02 ), the risk ratios being $0.5,1 \cdot 1$, and $1 \cdot 1$ respectively. Conversely, for lymphopoietic cancer, the risk ratios were inversely correlated with prior years of employment $(p=0.07)$, the ratios being 1.6 , $1 \cdot 0$, and 0.5 respectively.

Location specific analyses were initially based on independent external comparisons with the United States population for the six locations that contributed more than 100 people to the study. The four locations with similar operations (A, B, D, and E) were relatively homogenous with respect to overall and cause specific death rates (table 5) and did not differ significantly from the results for all locations combined. The most discrepant overall SMRs were observed for the two smallest locations, $\mathrm{F}$ and $\mathrm{C}$. The all causes and total cancer SMRs for the research and development centre, location F, were almost two thirds smaller than expected (SMRs $=38,35$ respectively). Location C's all cause mortality (SMR $=89$ ) was less than that of the United States population but was higher than that for the total cohort, and there was a twofold non-significant increase in total deaths from cancer $($ SMR $=220$ ) based on 8 observed and 3.6 expected deaths. Five of these deaths from cancer ( 1.4 expected) were specific to the lung and occurred among men with $\geqslant 20$ years priof employment who belonged to the operato $\bar{\phi}$ labourer/service job category in 1974. This excess resulted in a threefold statistically significant SME

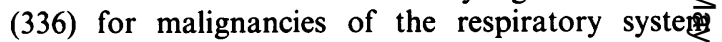
among white male employees at this plant.

The location $C$ analyses were replicated using the internal comparison procedure to contrast mortality for that location with the remaining surveillance locations, controlling for prior years of employmen job category, and interval since entry. The results of these comparisons were consistent with those of the external analyses. The conditional risk ratios we raised for total deaths from cancer (risk ratio $=2$ $\mathrm{p}=0.02$ ) and for deaths due to respiratory cance (risk ratio $=4.0, p=0.01$ ) with the deaths from respiratory cancer accounting for essentially all of the total cancer excess.

\section{Discussion}

The overall SMR of 67 (95\% CI: 55-72) for the study population was low as were the SMRs for many of the chronic diseases. These findings are consistent with the low SMRs typically observed for employed populations in the initial years of follow up and point to the importance of supplementing comparisons based on external general population death rates with interna comparisons. The large deficits in deaths due to acoig dental causes and suicide were not expected, sine initial selection effects would not be expected to operational for externally caused deaths. It may be, however, that the employees in this study, belonging to a long term working population $(\geqslant 10$ years \&f prior employment), had developed a stable lifestyle and a high degree of safety awareness.

There was one cause of death, malignant neoplasnos of the lymphatic and haematopoietic tissue, for which the SMR was notably above 100 . The deaths due 
lymphopoietic cancer ( 12 observed, $6 \cdot 8$ expected) were distributed most heavily in the job category associated with highest socioeconomic status ( 7 observed, $2 \cdot 3$ expected deaths). There were thus five deaths in the remaining two job groups compared with 4.5 expected. Since increased risk of lymphopoietic cancer with socioeconomic status has been reported in other settings, it appears unlikely that a casual link exists between these malignancies and the work environments under study. ${ }^{11}$

The internal comparisons by job category showed a general pattern of lowest risk ratios for supervisory, reseach, and office employees and highest risk ratios for the crafts group. An exception was the relatively higher risk of lymphopoietic cancer among job category A employees discussed above. The highest risk ratios for the crafts group were observed for the categories of cerebrovascular disease and diseases of the circulatory system. Within these categories the risk differential was greatest during the first five years of follow up and among men over age 50 at entry. For both the supervisory, research, and office group and the crafts group, mortality was higher during the first five years of observation in contrast to the operators, labourers, and service group, for whom the reverse was true. This observation suggests an additional selection issue. These groups may differ in the way in which prior health status relates to employment status (active $v$ non-active). For example, if less strenuous activity were required of a group, members of that group who have experienced chronic health problems might be better able to adjust to employment demands. In general, the interpretation of the job category findings is difficult. Job category itself may not be an adequate surrogate for either occupational exposures or socioeconomic group. In addition the assessment of findings may be hindered by the absence of smoking history information, since differentials in cigarette smoking by job category have been widely reported. ${ }^{912}$

Among the six locations studied, the most noteworthy finding was an excess of deaths from respiratory cancer at one of the smaller but older locations. Although this may represent a spurious case cluster identified in the course of examining multiple locations and disease entities, it warranted additional follow up efforts to determine possible alternative explanations. The respiratory cancer excess was not accounted for by regional differences in death rates, since the local county respiratory cancer death rates were only slightly higher than those of the United States for this period. Location $\mathrm{C}$ did differ from the remaining locations in that coal tar pitch was not known to have been used at the plant after 1928. In addition, location $\mathrm{C}$ was subject to a major reduction in its workforce in 1964. As indicated in table 1, the primary exposures of concern were to formaldehyde, silica, furfural, furfuryl alcohol, and asbestos. Formaldehyde, furfural, and furfuryl alcohol were used to treat the graphite parts which were, in turn, glued together with a carbonaceous cement composed of acetylene black and a phenolic resin. The potential for asbestos exposure is related to the cutting of gaskets and control boards from asbestos containing sheeting, the cutting of asbestos rope as a packing for sealing parts, and the use of asbestos blankets for insulation. All of these activities ended in the mid-1970s. Asbestos was commonly used at the other locations studied but the applications (siding, roofing, brake shoes, pipe covering, cement for furnaces) differed. Asbestos gaskets were also used at these locations but they were not cut to size on site, as they were at location C. Historical data documenting fibre size and type and levels of exposure by location are non-existent.

A review of the individual work history and medical records for the five subjects who died from respiratory cancer showed that they had smoked cigarettes, were hired after 1934, and had worked at least 25 years at the plant. At some point during their careers, each of them had worked in a section assigned to tasks involving potential exposure to asbestos in the final assembly of the parts. All the men had also worked shortly after hire in carbon brush manufacture which was one of the principal operations at the plant in early years. Only one of the men had worked in the area involving the initial treatment of the graphite. Although there are insufficient data to confirm that exposure to asbestos and cigarette smoking were concerned in the aetiology of these deaths, our review of the cases and plant operations could not identify any other risk factors to which this finding could be ascribed.

One of the reasons for our interest in this surveillance population was related to the use of coal tar pitch at most of the locations. Occupational mortality studies of workers exposed to coal tar products in the coke, steel, aluminium, and gas industries have reported an increased occurrence of cancer for a variety of sites including the respiratory system, skin, scrotum, and kidney. ${ }^{13-16}$ These outcomes were not found in significant excess among employees in the current study population. The SMR for respiratory cancer was 85 ; there were two deaths from skin cancer ( 1.5 expected deaths), no deaths from cancer of the scrotum, and three deaths from cancer of the kidney ( 2.2 expected deaths). These results do not indicate an adverse effect of pitch exposure on mortality in this workforce. Possible explanations for this finding include: (1) the surveillance strategy's low sensitivity to detect mortality excesses that may exist in small subgroups of the study population and (2) lower concentrations and therefore exposure to suspect carcino- 
genic polynuclear aromatic hydrocarbons due to the lower temperatures to which coal tar pitch is heated in the baked carbon industry. ${ }^{17}$ None of these mortality studies considers the occurrence of non-fatal diseases in pitch workers.

In conclusion, the existence of computerised payroll files for the carbon products division of Union Carbide Corporation provided us with an opportunity to develop and evaluate a population based approach to mortality surveillance. Our initial experience has been encouraging. Although the findings to date are limited by a relatively short observation period, valuable information has been obtained regarding the mortality experience of this population, and we are better able to establish research priorities. Additional follow up will improve power and provide an independent confirmation or lack thereof of the trends seen during the first 10 year observation period.

The technical help of Susie Lee, Antonio Soto, and Susan Hart is gratefully acknowledged. We thank Susan Austin for her conception and initiation of this project.

\section{References}

1 Ott MG, Carlo GL, Steinberg S, Bond GG. Mortality among employees engaged in chemical manufacturing and related activities. Am J Epidemiol 1985;122:311-22.

2 Rothman KJ, Boice JD Jr. Epidemiologic analysis with a programmable calculator. Washington: US Government Print Office, 1979:28-9. (DHEW publ No (NIH) 79-1649.)

3 Waxweiler RJ, Beaumont JJ, Henry JA, et al. A modified lifetable analysis system for cohort studies. J Occup Med 1983;25:115-24.
4 National Center for Health Statistics. Advance report of final mortality statistics, 1983. (Monthly vital statistics report 1985; vol 34, No 6, US Department of Health and Human Services. Washington: US Government Printing Office, 1985.)

5 Davis WB, Hayes CG, Knowles M, Riggan WB, Bruggen JV, Tyroler HA. Geographic variation in declining ischaemic heart disease mortality in the United States, 1968-1976. I. Rates and change, whites aged 35-74 years. Am J Epidemiol 1985;122:657-72.

6 Goldsmith JR. What do we expect from an occupational cohort? J Occup Med 1975;17:126-7.

7 McMichael AJ, Haynes SG, Tyroler HA. Observations on the evaluation of occupational mortality data. J Occup Med 1975;17:128-31.

8 Fox AJ, Collier PF. Low mortality rates in industrial cohort studies due to selection for work and survival in the industry. Br J Prev Soc Med 1976;30:225-9.

9 Ott MG. Effects of selection and confounding on mortality in an occupational cohort. Ann Arbor: University Microfilms International, 1982. (PhD dissertation.)

10 Miettinen OS. Standardisation of risk ratios. Am J Epidemiol 1972;96:383-8.

11 Registrar General. Occupational mortality, the registrar general's decennial supplement for England and Wales, 1970-1972. London: HMSO, 1978.

12 Sterling TD, Weinkam JJ. Smoking characteristics by type of employment. J Occup Med 1976;18:743-54.

13 Doll R, Vessey MP, Beasley RWR, et al. Mortality of gasworkers: final report of a prospective study. $\mathrm{Br} J$ Ind Med 1972;29:394-406.

14 Redmond CK, Ciocco A, Lloyd IW, Rush HW. Long-term mortality study of steelworkers. J Occup Med 1971;14:621-9.

15 Redmond CK, Strobino BR, Cypess RH. Cancer experience among coal by-product workers. Ann NY Acad Sci 1976;271:102-17.

16 Milham S. Mortality in aluminium reduction plant workers. $J$ Occup Med 1979;21:475-80.

17 International Agency for Research on Cancer. Monographs on the evaluation of the carcinogenic risk of chemicals to humans. Vol 35. Polynuclear aromatic compounds, part 4, bitumens, coal-tars and derived products, shale-oils and soots. Lyon: IARC, 1985:83-159.

\section{Destruction of manuscripts}

From 1 July 1985 articles submitted for publication will not be returned. Authors whose papers are rejected will be advised of the decision and the manuscripts will be kept under security for three months to deal with any inquiries and then destroyed. 